\title{
Translation and Linguistic Validation of the Korean Version of the "Benefit, Satisfaction, and Willingness to Continue" Questionnaire for Patients With Overactive Bladder
}

\author{
Sung Yong Cho ${ }^{1}$, Hahn-Ey Lee ${ }^{2}$, Seong Jin Jeong ${ }^{3}$, Seung-June $\mathrm{Oh}^{4}$ \\ ${ }^{1}$ Department of Urology, Seoul Metropolitan Government-Seoul National University Boramae Medical Center, Seoul, Korea \\ ${ }^{2}$ Pfizer Korea, Seoul, Korea \\ ${ }^{3}$ Department of Urology, Seoul National University Bundang Hospital, Seongnam, Korea \\ ${ }^{4}$ Department of Urology, Seoul National University Hospital, Seoul, Korea
}

\begin{abstract}
Purpose: The goal of this study was to develop a Korean version of the Benefit, Satisfaction, and Willingness to Continue (BSW) questionnaire from the original version, with subsequent linguistic validation by Korean patients with overactive bladder who undergo active treatment by a physician.

Methods: Translation and linguistic validation were performed in January 2013. The validation process included permission for translation, forward translation, reconciliation, backward translation, cognitive debriefing, and proofreading.

Results: During the forward translation process, the terms or phrases of 'benefit,' 'willingness, "have you had any benefit?," "taking all things into account" were adjusted to be more appropriate expressions in the Korean language than those used in the original version. During the backward translation process, no changes were made in terms of the sematic equivalence. In the cognitive debriefing session, 5 patients were asked to fill in the answers within 5 minutes; most reported that the translated questions were clear and easy to understand. One patient felt the questions were a little bit difficult to understand; however, the panel decided not to change the expressions because the overall level of comprehension was high and the translated terms were accurate enough to convey the meaning of the original version of the BSW.

Conclusions: The present study showed a successful linguistic validation of the BSW questionnaire. Further studies are needed to assess of the psychometric properties of the BSW.
\end{abstract}

Keywords: Quality of Life; Surverys and Questionnaires; Reproducibility of Results; Linguistics; Patient Satisfaction

- Research Ethics: This study was approved by the Institutional Review Board of Seoul National University Hospital (approval number: H-1305033-487).

- Conflict of Interest: No potential conflict of interest relevant to this article was reported.

\section{INTRODUCTION}

Overactive bladder $(\mathrm{OAB})$ is a chronic disease that usually requires an antimuscarinic agent, which has shown poor adherence, poor efficacy, and frequent adverse effects within 3 months of use [1,2]. Patients becoming dissatisfied with their treatment is closely related to treatment failure. Therefore, health-related quality of life has been actively assessed, and the concept of patient-reported outcomes (PRO) has been introduced [3]. Implementing PRO involves assessing patient satis-
Corresponding author: Seung-June Oh (iD http://orcid.org/0000-0002-0322-3539 Department of Urology, Seoul National University Hospital, Seoul National University College of Medicine, 101 Daehak-ro, Jongno-gu, Seoul 03080, Korea E-mail: sjo@snu.ac.kr / Tel: +82-2-2072-2406 / Fax: +82-2-742-4665

Submitted: March 14, 2016 / Accepted after revision: April 2, 2016
This is an Open Access article distributed under the terms of the Creative Commons Attribution Non-Commercial License (http://creativecommons.org/licenses/by-nc/4.0/) which permits unrestricted non-commercial use, distribution, and reproduction in any medium, provided the original work is properly cited. 
faction with treatment in clinics by examining individual medical needs, perceived benefits, and patients' concerns and expectations. Patient satisfaction ultimately affects the decision of willingness to continue the treatment provided by the physicians or the clinic.

The Benefit, Satisfaction, and Willingness to Continue (BSW) questionnaire has been recently developed for patients with OAB to assess PRO [4]. Patients are asked to provide their general impressions of benefit, satisfaction with treatment, and willingness to continue treatment, which are helpful to quantify the subjective relief of symptoms, impact on daily lives, and side effects. Patients can weigh the benefits and harms, and provide a global response to physicians. This could facilitate the physician-patient relationship and increase medication compliance for $\mathrm{OAB}$.

Up to this point, a Korean version of the BSW was not available to patients. Therefore, authors of the present study developed a Korean version of the BSW questionnaire from the original, with subsequent linguistic validation in Korean patients with $\mathrm{OAB}$ who underwent active treatment by a physician.

\section{MATERIALS AND METHODS}

\section{Original BSW Questionnaire}

The BSW was developed by the Pfizer Corporation and is administered by physicians. It consists of 3 patient-rated global assessments of treatment benefit (little vs. much benefit), satisfaction with treatment (little vs. very satisfied and little vs. very dissatisfied), and willingness to continue treatment (little vs. very willing and little vs. very unwilling).

\section{Translation and Linguistic Validation}

This study was approved by the Institutional Review Board of Seoul National University Hospital (approval number: H-1305033-487). The procedure was designed to obtain a translated Korean version of the questionnaire, which is conceptually equivalent to the original. The translation was appropriate according to the cultural adaptation and performed by the project leader of the panel. This panel consisted of three Korean experts (SJO, SYC, and SJJ) who performed a typical linguistic validation process.

\section{Permission}

Before the study commenced, the panel contacted the Pfizer Corporation and acquired permission to translate and use the
BSW with the linguistic validation process.

\section{Forward translation}

The original version of the BSW was translated into the Korean language (ver. 1.0a and 1.0b) by 2 bilingual translators who do not have medical licenses. The translations were performed independently, and the translators were not permitted to contact each other during the translation process.

\section{Reconciliation by the panel}

The independently translated versions in the Korean language (ver. 1.0a and 1.0b) were reconciled into a single version after several panel meetings (ver. 1.1). The panel discussed comprehension difficulties due to subtle differences in the nuance of selected words and phrases.

\section{Backward translation}

The reconciled version of the BSW in the Korean language (ver. 1.1) was sent to a third bilingual translator. This translator translated it backward into the English version, which was compared to the original English version of the BSW. After the third translator completed the backward translation, the panel discussed the discrepancies between the original and the backward-translated version of the BSW. Some changes were made in the reconciled BSW in the Korean language based on the outcomes of several discussions (ver. 1.2).

\section{Cognitive debriefing}

Next, version 1.2 of the questionnaire was evaluated by 5 Korean-speaking patients with $\mathrm{OAB}$, who were asked whether or not there were any clarity problems, culturally inappropriate feelings, or difficulties in understanding. The panel chose a trained interviewer who performed a standardized in-depth interview with a small number of patients. The debriefing interviews involved paraphrasing each question of the questionnaire and indicating whether there was any difficulty understanding or any confusing terms. Then, the panel discussed the feedback from the 5 patients with $\mathrm{OAB}$ and agreed to a new version based on the issues raised (ver. 1.3).

\section{Proofreading}

Version 1.3 was proofread to check spelling, grammar, and format. Afterwards, the panel obtained the final version of the BSW in the Korean language (ver. 1.4). 


\section{RESULTS}

\section{Forward Translation and Reconciliation}

As shown in Table 1, the word 'benefit' in the title of the original version was translated into 'hyogwa' (efficacy or effect) and 'chilyohyetaeg' (treatment benefit) by the translators, which was finally reconciled into 'chilyohyetaeg' (treatment benefit). 'Willingness' in the title was translated into 'uihyang' and 'uiji', which was reconciled into 'uihyang.' The panel thought that 'uihyang' gives the impression that patients are fairly happy about doing it and would do it if they were asked or required to do it more so than the word 'uiji'.
Question 1, "Have you had any benefit from your treatment?" in the original version was directly translated into "Hyetaegeul badeun jeogi issseubnikka?" (Have you experienced any benefit?). However, the panel reconciled it into "Hyetaegeul badassseubnikka?" (Did you have any benefit?), because this sentence would be more natural and equal to the meaning of the original version based on cultural adaptation.

Question 2, "Taking all things into account" in the original version was translated into "modeun myeoneul golyeohaesseul ttae" (taking all angles of the question into account) because the term, 'things' has an expansive definition of 'geot', (objects or stuff) 'myeon', (aspects) etc. Therefore, the panel agreed to

Table 1. Reconciliation after two forward translations

\begin{tabular}{|c|c|c|c|}
\hline US English item & $\begin{array}{l}\text { First forward } \\
\text { Korean translation }\end{array}$ & $\begin{array}{l}\text { Second forward } \\
\text { Korean translation }\end{array}$ & $\begin{array}{l}\text { Reconciled forward } \\
\text { Korean translation }\end{array}$ \\
\hline $\begin{array}{l}\text { Benefit, Satisfaction, and Willingness to Continue } \\
\text { (BSW) Questions }\end{array}$ & $\begin{array}{l}\text { 효과, 만족도, 치료를 지속하고 } \\
\text { 싶은 의향(BSW설문) }\end{array}$ & $\begin{array}{l}\text { 혜택, 만족도, 그리고 지속하고자 } \\
\text { 하는 의지에 관한 질문 }\end{array}$ & $\begin{array}{l}\text { 치료 혜택, 만족도와 치료 지속 의 } \\
\text { 향 }\end{array}$ \\
\hline $\begin{array}{l}\text { The following questions are administered by } \\
\text { the physician }\end{array}$ & $\begin{array}{l}\text { 다음의 질문들은 의사의 관리 아 } \\
\text { 래에 있습니다. }\end{array}$ & $\begin{array}{l}\text { 다음 질문 사항들은 내과의사가 } \\
\text { 집행한다. }\end{array}$ & $\begin{array}{l}\text { 다음의 질문들은 의사에 의해 관 } \\
\text { 리됩니다. }\end{array}$ \\
\hline BENEFIT: Please ask the patient the following question: & $\begin{array}{l}\text { 효과: 환자에게 다음의 질문을 해 } \\
\text { 주세요. }\end{array}$ & $\begin{array}{l}\text { 혜택: 환자에게 다음과 같이 질문 } \\
\text { 하십시오. }\end{array}$ & $\begin{array}{l}\text { 치료 혜택: 환자에게 다음 질문을 } \\
\text { 해주세요. }\end{array}$ \\
\hline Have you had any benefit from your treatment? & $\begin{array}{l}\text { 지금까지 이 치료를 통해 얻은 효 } \\
\text { 과가 있습니까? }\end{array}$ & 치료가 효과적이었나요? & $\begin{array}{l}\text { 귀하는 치료를 통해서 혜택을 받 } \\
\text { 았습니까? }\end{array}$ \\
\hline If YES, please ask the patient the following question & $\begin{array}{l}\text { ‘예’ 인 경우 환자에게 다음의 } \\
\text { 질문들을 해 주세요. }\end{array}$ & $\begin{array}{l}\text { “예” 라고 대답한 환자들에게 } \\
\text { 다음과 같이 질문 해 주세요. }\end{array}$ & $\begin{array}{l}\text { ‘예' 라고 대답한 경우, 환자에 } \\
\text { 게 다음 질문을 해 주세요. }\end{array}$ \\
\hline $\begin{array}{l}\text { Have you had little benefit from your treatment or } \\
\text { much benefit? }\end{array}$ & $\begin{array}{l}\text { 이 치료를 통해서 적은 또는 많은 } \\
\text { 효과를 보셨습니까? }\end{array}$ & $\begin{array}{l}\text { 치료를 통해 효과를 적게 받았나 } \\
\text { 요 혹은 많이 받았나요? }\end{array}$ & $\begin{array}{l}\text { 귀하는 치료를 통해서 혜택을 적 } \\
\text { 게 받았습니까 혹은 많이 받았습 } \\
\text { 니까? }\end{array}$ \\
\hline (1) Little benefit/ (2) Much benefit & (1) 적은 효과 / (2) 많은 효과 & $\begin{array}{l}\text { (1) 효과가 적었다 (2) 효과가 좋 } \\
\text { 았다 }\end{array}$ & $\begin{array}{l}\text { (1) 혜택이 적었다 / (2) 혜택이 많 } \\
\text { 았다 }\end{array}$ \\
\hline $\begin{array}{l}\text { SATISFACTION: Please ask the patient the } \\
\text { following question: }\end{array}$ & $\begin{array}{l}\text { 만족도: 환자에게 다음의 질문을 } \\
\text { 해 주세요. }\end{array}$ & $\begin{array}{l}\text { 만족도: 환자에게 다음과 같이 질 } \\
\text { 문 해 주십시오: }\end{array}$ & $\begin{array}{l}\text { 만족도: 환자에게 다음 질문을 해 } \\
\text { 주세요. }\end{array}$ \\
\hline $\begin{array}{l}\text { Taking all things into account, are you satisfied } \\
\text { with your treatment? }\end{array}$ & $\begin{array}{l}\text { 모든 것을 통합해서 볼 때 이 치료 } \\
\text { 에 만족하십니까? }\end{array}$ & $\begin{array}{l}\text { 모든 면에서 고려했을 시, 치료에 } \\
\text { 대하여 만족스러운가요? }\end{array}$ & $\begin{array}{l}\text { 모든 면을 고려했을 때, 귀하는 치 } \\
\text { 료에 만족하십니까? }\end{array}$ \\
\hline $\begin{array}{l}\text { Are you a little satisfied with your treatment or } \\
\text { very satisfied with your treatment? }\end{array}$ & $\begin{array}{l}\text { 이 치료에 조금 또는 매우 만족하 } \\
\text { 십니까? }\end{array}$ & $\begin{array}{l}\text { 치료받은 사항에 대해서 매우 만 } \\
\text { 족스럽습니까 혹은 만족스럽지 않 } \\
\text { 으십니까? }\end{array}$ & $\begin{array}{l}\text { 귀하는 치료에 약간 만족하십니까 } \\
\text { 혹은 매우 만족하십니까? }\end{array}$ \\
\hline If NO, please ask the patient the following question & $\begin{array}{l}\text { ‘아니오' 인 경우 환자에게 다 } \\
\text { 음의 질문들을 해 주세요. }\end{array}$ & $\begin{array}{l}\text { "아니오" 라고 대답했을 시, 다 } \\
\text { 음 질문을 해 주십시오. }\end{array}$ & $\begin{array}{l}\text { '아니오' 라고 대답한 경우, 환 } \\
\text { 자에게 다음 질문을 해 주세요. }\end{array}$ \\
\hline $\begin{array}{l}\text { Are you a little dissatisfied with your treatment or } \\
\text { very dissatisfied with your treatment? }\end{array}$ & $\begin{array}{l}\text { 이 치료가 조금 또는 매우 불만족 } \\
\text { 스러웠습니까? }\end{array}$ & $\begin{array}{l}\text { 치료받은 사항에 대해서 조금 불 } \\
\text { 만족스러우십니까 혹은 매우 불만 } \\
\text { 족스러우십니까? }\end{array}$ & $\begin{array}{l}\text { 귀하는 치료에 대해 약간 불만족 } \\
\text { 스럽습니까? 혹은 매우 불만족스 } \\
\text { 럽습니까? }\end{array}$ \\
\hline $\begin{array}{l}\text { Would you be willing to continue treatment } \\
\text { with this medication? }\end{array}$ & $\begin{array}{l}\text { 이 약으로 계속 치료를 받고 싶으 } \\
\text { 십니까? }\end{array}$ & $\begin{array}{l}\text { 동일한 약물로 치료를 지속하길 } \\
\text { 원하십니까? }\end{array}$ & $\begin{array}{l}\text { 귀하는 이 ㅇㅑㅑ으로 치료를 지속하 } \\
\text { 고 싶은 의향이 있습니까? }\end{array}$ \\
\hline $\begin{array}{l}\text { Would you be a little bit willing to continue treatment with } \\
\text { this medication or very willing to continue treatment } \\
\text { with this medication? }\end{array}$ & $\begin{array}{l}\text { 이 약을 사용한 치료를 계속 받고 } \\
\text { 싶으실 의향이 조금 또는 많이 있 } \\
\text { 으십니까? }\end{array}$ & $\begin{array}{l}\text { 동일한 약물로 치료를 지속하길 } \\
\text { 원하십니까? }\end{array}$ & $\begin{array}{l}\text { 귀하는 이 약으로 치료를 지속하 } \\
\text { 고 싶은 의향이 약간 있습니까? } \\
\text { 혹은 많이 있습니까? }\end{array}$ \\
\hline $\begin{array}{l}\text { Would you be a little bit unwilling to continue treatment } \\
\text { with this medication or very unwilling to continue } \\
\text { treatment with this medication? }\end{array}$ & $\begin{array}{l}\text { 이 약을 사용한 치료를 더 이상 받 } \\
\text { 고 싶지 않을 의향이 조금 또는 많 } \\
\text { 이 있으십니까? }\end{array}$ & $\begin{array}{l}\text { 동일한 약물로 치료를 지속하길 } \\
\text { 원하십니까? }\end{array}$ & $\begin{array}{l}\text { 귀하는 이 약으로 치료를 지속하 } \\
\text { 고 싶은 의향이 약간 없습니까? } \\
\text { 혹은 많이 없습니까? }\end{array}$ \\
\hline
\end{tabular}


specify the meaning of 'things.'

Question 3, "Would you be a little bit unwilling to continue treatment with this medication?" in the original version was translated into "Gwihaneun i yageulo chilyoleul jisoghago sipeun uihyangi yaggan eobsseubnikka?". The panel discussed which would be more appropriate between "Uihyangi yaggan eobsseubnikka?" (unwilling to continue treatment?) and "Naekiji anhseubnikka?" (reluctant to continue treatment?). The latter is a more natural expression in the Korean language than the former in terms of conceptual equivalence. Therefore, the panel decided to choose the latter expression to convey the meaning exactly.

\section{Backward Translation}

As shown in Table 2, the panel discussed the differences between "Have you had any benefit?" in the original version and "Did you have any benefit?" in the reconciled version. The panel did not think that there was a large difference in meaning between "Have you had any...?" and "Did you have any...?" in this particular case. Thus, the translated sentence was left as is to acquire idiomatic equivalence.

The 3 translators discussed the translated term 'yaggan' in the Korean language and 'a little' in the English language in terms of sematic equivalence. They agreed on the possible confusion that 'yaggan' would have both meanings of 'a little' and 'somewhat.' The panel finally decided not to change the term.

\section{Cognitive Debriefing and Proofreading}

The translation was tested by four patients with $\mathrm{OAB}$ who underwent medical therapy. Two patients were women and 2 were men, ranging in age from 30s to 70s. Their levels of education varied from illiterate to university graduate. Three were employed and the other was a housewife. All patients completed the answers within 5 minutes. Three reported that the translated questions were clear and easy to understand; however, one patient felt that the questions were a bit difficult to understand, and pointed out the awkward expression of the above-mentioned problem between "Uihyangi yaggan eobsseubnikka?" (unwilling to continue treatment?) and "Naekiji anhseubnikka?" (reluctant to continue treatment?). However, the panel decided not to change the expressions because the overall level of comprehension was high and the translated terms were accurate enough to convey the meaning of the original BSW version. The final conclusion of the questionnaire is shown in the Fig. 1.

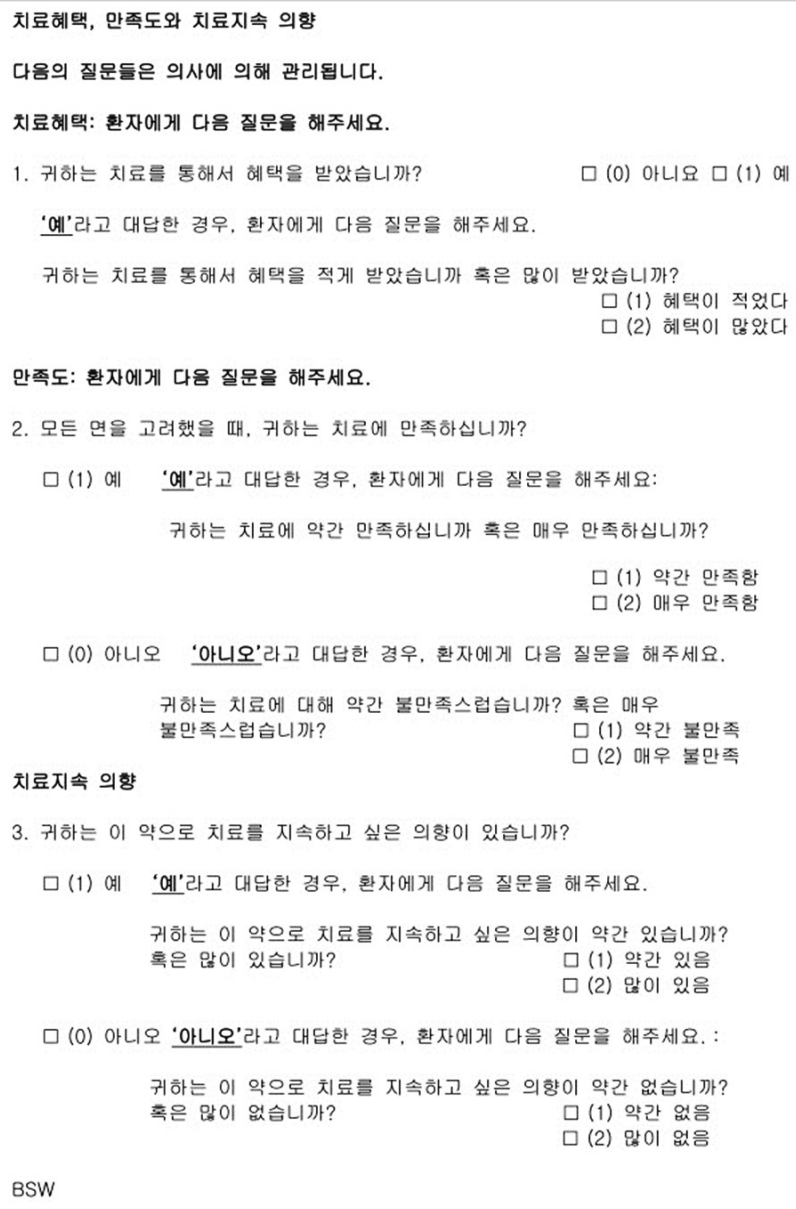

3. 귀하는 이 약으로 치료를 지속하고 싶은 의향이 있습니까?

ㅁ(1)예 '예'라고 대답한 경우, 환자에게 다음 질문을 해주세요. 귀하는 이 약으로 치료를 지속하고 싶은 의향이 약간 있습니까? 톡은 않이 있습니까? $\quad \square(1)$ 약간 있음

ㅁ (2) 않이 있음

$\square(0)$ 아니오 아니오'라고 대답한 경우, 환자에게 다음 질문을 해주세요. :

귀하는 이 약으로 치료를 지속하고 싶은 의향이 약간 없습니까? 혹은 않이 없습니까? ㅁ(1) 약간 없응 $\square$ (2) 않이 없음

BSW

Fig. 1. Korean version of the Benefit, Satisfaction, and Willingness to Continue (BSW) questionnaire for patients with overactive bladder.

Table 2. Backward translation

\begin{tabular}{llc}
\hline Original & \multicolumn{1}{c}{ Forward translation } & \multicolumn{1}{c}{ Back translation } \\
\hline $\begin{array}{l}\text { Have you had any benefit from your treatment? } \\
\begin{array}{l}\text { Are you a little satisfied with your treatment or } \\
\text { very satisfied with your treatment? }\end{array}\end{array}$ & $\begin{array}{l}\text { 귀하는 치료를 통해서 혜텍을 받았습니간 만족하십니까 혹은 매우 만족하십니 } \\
\text { 까? }\end{array}$ & $\begin{array}{c}\text { Are you somewhat satisfied or very satisfied? } \\
\text { medical treatment? }\end{array}$ \\
\hline
\end{tabular}




\section{DISCUSSION}

In general, $\mathrm{OAB}$ is diagnosed based on subjective symptoms, such as urgency, frequency, and/or nocturia. However, $O A B$ is a chronic disease that requires long-term medication therapy, which is why the patient's perspective is important. Persistence is particularly important in cases of long-term medication therapy, as patients' satisfaction with the therapy is closely related to medication compliance.

Previous investigations have measured the severity of $\mathrm{OAB}$ symptoms and their impact on quality of life $[3,5]$. King's Health Questionnaire [6] and the OAB questionnaire [7] are appropriate for evaluating bothersomeness caused by each symptom and its effect on daily quality of life. However, these questionnaires have too many questions for patients to fill in quickly in the outpatient department and they seem to be more appropriate for a clinical study instead of a daily practice. The Overactive Bladder Symptom Score has been developed recently, which is comprised of only 4 questions regarding frequency, nocturia, urgency, and urgency urinary incontinence [8]. This is simple and easy to complete, however, it does not have any questions regarding bothersomeness or effects on daily life. Therefore, the authors of this study thought that these questionnaires are limited in directly evaluating perspectives on the medication therapy of patients with OAB. Previous studies showed that there was discrepancy between the severity of $\mathrm{OAB}$ symptoms and bothersomeness [9]. Furthermore, longterm medication with anticholinergic agents showed poor compliance and persistence regardless of the type of the agents [2]. Therefore, a direct evaluation of the patients perspective is needed to increase drug compliance and persistence.

The BSW questionnaire directly evaluates patients' global assessment of treatment benefit, satisfaction with treatment and willingness to continue treatment [4]. Because the results of the BSW seemed to be more directly related to treatment compliance and persistence than other previously reported questionnaires, the original version of the BSW questionnaire has been validated in other languages [10]. Therefore, information from these studies would be helpful to domestic investigators for use of the Korean version of the BSW to assess treatment response, increase patients' compliance, and determine a treatment plan for patients with $\mathrm{OAB}$.

In conclusion, the present study carried out a successful linguistic validation of the BSW questionnaire. Further studies are needed to assess of the psychometric properties of the BSW.

\section{REFERENCES}

1. Veenboer PW, Bosch JL. Long-term adherence to antimuscarinic therapy in everyday practice: a systematic review. J Urol 2014;191: 1003-8.

2. Sicras-Mainar A, Rejas J, Navarro-Artieda R, Aguado-Jodar A, Ruiz-Torrejón A, Ibáñez-Nolla J, et al. Antimuscarinic persistence patterns in newly treated patients with overactive bladder: a retrospective comparative analysis. Int Urogynecol J 2014;25:485-92.

3. Kim TH, Choo MS, Kim YJ, Koh H, Lee KS. Drug persistence and compliance affect patient-reported outcomes in overactive bladder syndrome. Qual Life Res 2016;25:2021-9.

4. Pleil AM, Coyne KS, Reese PR, Jumadilova Z, Rovner ES, Kelleher CJ. The validation of patient-rated global assessments of treatment benefit, satisfaction, and willingness to continue--the BSW. Value Health 2005;8 Suppl 1:S25-34.

5. Khullar V, Amarenco G, Angulo JC, Blauwet MB, Nazir J, Odeyemi IA, et al. Patient-reported outcomes with the $\beta 3$-adrenoceptor agonist mirabegron in a phase III trial in patients with overactive bladder. Neurourol Urodyn 2015 Aug 19 [Epub].http://dx.doi.org/10.1002/nau.22844.

6. Margolis MK, Vats V, Coyne KS, Kelleher C. Establishing the content validity of the King's Health Questionnaire in men and women with overactive bladder in the US. Patient 2011;4:177-87.

7. Oh SJ, Son H, Kim SW, Lee KS, Choo MS, Kim SO, et al. Psychometric Properties of the Korean version of the overactive bladder questionnaire (OAB-q) in a Korean population. Int Neurourol J 2012;16:77-85.

8. Homma Y, Yoshida M, Seki N, Yokoyama O, Kakizaki H, Gotoh M, et al. Symptom assessment tool for overactive bladder syndrome-overactive bladder symptom score. Urology 2006;68:318-23.

9. Homma Y, Gotoh M. Symptom severity and patient perceptions in overactive bladder: how are they related? BJU Int 2009;104:968-72.

10. Jiménez MA, Cambronero J. Validation of the Spanish version of the questionnaire «Benefit, satisfaction and willingness to continue the treatment» in patients with overactive bladder. Actas Urol Esp 2013;37:473-9. 